\title{
WALIDACJA SKALI WIZERUNKU MIEJSCOWOŚCI - PIERWSZA FAZA BADAŃ
}

\begin{abstract}
Zarys treści: $W$ artykule zaprezentowana została idea wizerunku miejscowości oraz przegląd wybranych metod i narzędzi pomiaru tej cechy oraz jej podobnych. Następnie zaprezentowano wyniki badań nad autorskim instrumentem do pomiaru wizerunku miejscowości, jakim jest miasto i wieś. W badaniu uczestniczyło 400 mieszkańców miasta i podmiejskich miejscowości. W wyniku zastosowanej analizy czynnikowej ustalono, że struktura skali przyjmuje postać trójskładnikową. Parametry psychometryczne pozycji skali okazały się zadowalające, a współczynniki jej spójności wewnętrznej odpowiednio wysokie.
\end{abstract}

Słowa kluczowe: Skala Wizerunku Miejscowości, pomiar, walidacja.

\section{Wprowadzenie}

Wizerunek miejscowości traktowany jest zwykle jako konstrukt poznawczy, jakim posługuje się osoba spostrzegająca miejscowość lub przywołująca jego obraz z pamięci. Na obraz ten składają się przeróżne elementy i aspekty, począwszy od cech przestrzennych miejscowości, poprzez jej własności demograficzne, ekonomiczne, gospodarcze, społeczne, kulturowe, aż po symboliczne. Treść tych przywołań może być uwarunkowana zbiorowym lub indywidualnym doświadczeniem odnoszonym do miejsca, jak też przekazami, które różnymi kanałami informacyjnymi docierają do podmiotów spostrzegających.

Badacze są stosunkowo zgodni w wyodrębnianiu $\mathrm{z}$ wizerunku miasta lub miejsca komponentu kognitywnego oraz afektywnego (Gallarza, Saura, Garcia 2002; Majer 2010; Dudek-Mańkowska 2011). To czyni ten konstrukt podobnym do pojęcia postawy zwłaszcza, gdy mowa o triarchicznej jej koncepcji. Jest tak tym bardziej, gdy model wizerunku miasta uwzględnia komponent konatywny (por. Florek, Glińska, Kowalewska 2009). W prezentowanym niżej badaniu uwaga skupiona została raczej na kwestii obrazu czy też wyobrażeń i oczekiwań, jakie $\mathrm{w}$ indywidualnej percepcji wiążą się z zamieszkiwaną miejscowością. Ale 
warto mieć na uwadze, że zgodnie z soczewkowym modelem postawy (Wojciszke 2011), wizerunek obiektu jako własność mająca poznawczy charakter i której podmiot nadaje walencję, może być $\mathrm{z}$ jednej strony czynnikiem warunkującym postawy, a z drugiej stanowić efekt postaw już istniejących.

Oprócz postawy, z wizerunkiem miejscowości nie trudno również skojarzyć pojęcie przywiązania do miejsca (por. Sztabiński, Sztabiński 1997; Michalska 2002; Michalska 2003; Lewicka 2005). Jedno i drugie, w odniesieniu do przedstawionego niżej zagadnienia walidacji narzędzi pomiaru, jest kluczowe, gdyż pozwala poszerzać repertuar instrumentów w prowadzeniu równoległych pomiarów będących podstawą oceny trafności kryterialnej testowanego narzędzia. Co więcej, w kontekście zagadnienia zmian i innowacji zachodzących w obszarach miejskich i wiejskich, kojarzenie kwestii wizerunku miejscowości z procesami rozwijania się i funkcjonowania postaw zyskuje mocne uzasadnienie. Wystarczy przywołać ideę zaufania społecznego w przestrzeni miejskiego życia (por. Starosta, Brzeziński 2014) lub warunków suburbanizacji i kontrurbanizacji (por. Dej, Zajda 2016).

Badania wizerunku miejscowości mają znaczenie dla oceny jakości życia, podejmowania działań naprawczych, rozpoznawania stosunku wobec miejscowości i jej aspektów, ale także diagnozy obszarów wymagających interwencji, np. w postaci oddziaływań edukacyjnych. Niebagatelną rolę odgrywać może ta cecha w wyznaczaniu stosunku wobec wdrażania innowacji oraz określaniu indywidualnego i społecznego zapotrzebowania na dokonywanie innowacyjnych zmian w obszarze życia danej miejscowości. Za słusznością takiego stanowiska przemawiają funkcje, które przypisuje się wizerunkowi miejscowości, a do których należą na przykład: determinowanie identyfikacji z miejscem, zainteresowanie miejscowością i jego rozwojem, wyznaczanie zaufania wobec władz lokalnych (por. Florek, Glińska, Kowalewska 2009; Dudek-Mańkowska 2011). Wizerunek miejscowości bywa również traktowany jako istotny element kapitału terytorialnego (por. Tobiasz-Lis 2016). Do głównych czynników warunkujących powstanie, rozwój i własności wizerunku miejscowości należy grupa cech podmiotowych i pozapodmiotowych (por. Jenkins 1999; Dudek-Mańkowska 2011). Wśród tych pierwszych znajduje się indywidualne doświadczenie, indywidualne charakterystyki, w tym wykształcenie. $Z$ kolei do istotnych czynników pozapodmiotowych zalicza się działanie lokalnych władz, mediów, innych podmiotów oraz cechy fizyczne i geograficzne miejscowości.

\section{Pomiar wizerunku miejsca i miejscowości}

W praktyce pomiarów wizerunku miejscowości, czy szerzej - miejsca, stosuje się zróżnicowaną metodologię, choć jedynie nieliczne rozwiązania podparte są działaniami zabezpieczającymi ich trafność i rzetelność. Wśród jednych z naj- 
popularniejszych metod, czy też schematów badań, znajduje się sondaż, który realizowany jest zwykle w postaci ankiet oraz wywiadów. Obie te postaci służą zwykle badaniu opinii społecznej. Rzadziej wycelowane są w rozpoznanie posiadanych przez indywidualne podmioty wizerunków miejscowości lub miejsca. Walor diagnozy indywidualnej trudno przecenić, gdyż pozwala ona wydzielać jednostki w populacjach miejscowości pod kątem możliwości pogłębiania rozpoznania indywidualnych potrzeb i doświadczeń oraz projektowania w odpowiedzi adekwatnych działań. Rozpoznanie potrzeb i trudności oraz odpowiadający temu dobór rozwiązań ma znaczenie dla rządowych i pozarządowych organizacji prowadzących własne obserwacje problemów społecznych występujących w regionie, który obejmują one monitoringiem (Zajda 2017a; Zajda 2017b). Jednakże tego rodzaju narzędzi jest niewiele, w szczególności instrumentów o ustabilizowanej charakterystyce psychometrycznej zapewniającej uzyskiwanie wiarygodnych pomiarów indywidualnych wizerunków miejscowości i miejsca. Do nielicznych udanych prób zaliczyć można badania nad podnoszeniem trafności i rzetelności badań sondażowych nad obrazem miejsca przeznaczenia (destination of image) (Dolnicar, Grun 2013), jak też indeks atrybutów wizerunku miasta (Nowacki, Zmyślony 2011). Istnieją również pomiary bazujące na szacowaniu obrazów określonych regionów miasta pod względem zadanej puli kryteriów (Salesses, Schechtner, Hidalgo 2013). Jest wreszcie kanoniczny scenariusz wywiadu Kevina Lyncha (1960/1990), a podsumowanie najpopularniejszych sposobów pomiaru wizerunku miejsca odnaleźć można w pracy autorstwa Charlotte Echtner i J.R. Brent Ritchie (2003). Spośród instrumentów możliwych do kojarzenia z pomiarami wizerunku miejscowości warto przywołać test The Measure of Place Attachement i jego polską adaptację o nazwie Skala Przywiązania do Miejsca (Mandal, Moroń 2016).

Celem artykułu jest przedstawienie rezultatów pierwszej fazy walidacji nowego autorskiego narzędzia do badania wizerunku miejscowości. Jego konstrukcja motywowana była z jednej strony dostrzeżeniem niedostatków narzędzi już funkcjonujących w literaturze przedmiotu, $\mathrm{z}$ drugiej, zdawaniem sobie sprawy z wagi użycia w praktyce takich instrumentów, które pomagają ujawniać subiektywne spostrzegania miejscowości przez ich mieszkańców. Bowiem efektywność zmian, w szczególności o charakterze innowacji społecznych, wprowadzanych w obszarach miejskich i wiejskich uzależniona jest od wcześniejszego rozpoznania istniejących warunków. Wizerunek miejscowości jakim dysponują jednostki, grupy i społeczne kategorie osób jest jednym z nich.

Zgodnie z powyższym proponowana Skala Wizerunku Miejscowości jest instrumentem powstałym $\mathrm{w}$ odpowiedzi na dostrzeżenie potrzeby uzyskiwania bardziej dokładnych i skoncentrowanych pomiarów niż te, które dostarczają doraźnie konstruowane ankiety, kwestionariusze wywiadów oraz scenariusze wywiadu. Poza tym wychodzi naprzeciw istniejącej luce, gdyż zwykle zaintereso- 
wania wizerunkiem miast, miejscowości czy miejsc lokują się w kontekście badań nad turystyką, a to oznacza, że ich przedmiotem jest obraz posiadany przez podmioty nie zamieszkujące danego obszaru. Takie badania i instrumenty konstruowane na ich potrzeby skupione są na innego rodzaju potrzebach i motywacjach podmiotów spostrzegających.

Podstawowe pytanie, które poprzedziło badanie dotyczyło struktury i właściwości cechy jaką jest subiektywny wizerunek miejscowości.

\section{Metoda badań}

\section{Uczestnicy}

W badaniu wzięło udział 400 mieszkańców Słupska i gminy Słupsk, tj. 367 słupszczan i 33 mieszkańców podmiejskich wsi (Kobylnica, Krępa Słupska, Bierkowo, Bruskowo Wielkie, Łosino, Włynkówko, Jezierzyce Słupskie, Głobino, Redzikowo, Siemianice). W próbie znalazło się 270 kobiet i 130 mężczyzn w wieku około 37 lat z przeciętnym okresem zamieszkiwania w Słupsku lub gminie wynoszącym 26 lat. Charakterystyka tych cech z uwzględnieniem podziału na płeć zaprezentowana została w tabeli 1. Rozkłady wieku i czasu zamieszkiwania w grupie kobiet i mężczyzn charakteryzowały się podobnymi właściwościami, choć mężczyźni okazali się nieznacznie mniej zróżnicowani pod względem mierzonych zmiennych, na co wskazują wartości odchyleń standardowych oraz kurtozy.

Tabela 1. Statystyki opisowe zmiennych wiek metrykalny oraz czas zamieszkiwania

\begin{tabular}{|c|c|c|c|c|c|c|c|c|c|c|}
\hline Grupa & Zmienna & $\mathrm{n}$ & $\mathrm{m}$ & me & $\min$ & $\max$ & sd & $\mathrm{V}$ & As & $\mathrm{K}$ \\
\hline \multirow[b]{2}{*}{ Kobiety } & wiek & 268 & 37,27 & 35 & 14 & 74 & 13,56 & 36,38 & 0,70 & $-0,29$ \\
\hline & $\begin{array}{c}\text { czas } \\
\text { zamieszki- } \\
\text { wania (lata) }\end{array}$ & 270 & 25,92 & 27 & 0,5 & 65 & 17,11 & 66,03 & 0,21 & $-0,94$ \\
\hline \multirow[b]{2}{*}{ Mężczyźni } & wiek & 130 & 35,28 & 34 & 15 & 77 & 11,86 & 33,63 & 1,05 & 1,33 \\
\hline & $\begin{array}{c}\text { czas } \\
\text { zamieszki- } \\
\text { wania (lata) }\end{array}$ & 130 & 25,52 & 26 & 1 & 60 & 14,07 & 55,13 & 0,03 & $-0,53$ \\
\hline \multirow[b]{2}{*}{ Ogółem } & wiek & 398 & 36,62 & 34 & 14 & 77 & 13,05 & 35,63 & 0,80 & 0,09 \\
\hline & $\begin{array}{c}\text { czas } \\
\text { zamieszki- } \\
\text { wania (lata) }\end{array}$ & 400 & 25,79 & 26 & 0,5 & 65 & 16,17 & 62,70 & 0,18 & $-0,80$ \\
\hline
\end{tabular}

Objaśnienia: $\mathrm{n}$ - liczebność próby, $\mathrm{m}$ - średnia arytmetyczna, me - mediana, min - wynik najniższy, max - wynik najwyższy, sd - odchylenie standardowe, V - współczynnik zmienności, As - współczynnik skośności, K - współczynnik spłaszczenia.

Źródło: opracowanie własne 
Informacje zestawione $\mathrm{w}$ tabeli 2 wskazują, że w próbie zdecydowanie przeważały osoby z wykształceniem wyższym. Rozkład częstości wariantów cechy wykształcenie w grupie mężczyzn i kobiet był podobny uwidoczniając nieznaczny udział osób $\mathrm{z}$ wykształceniem niższym niż średnie. Taka charakterystyka zwiększa prawdopodobieństwo, że odpowiedzi na pozycje testu warunkowane były faktycznym rozumieniem ich brzmienia oraz dostateczną zdolnością oceny i werbalizacji indywidualnych oszacowań, co ma kluczowe znaczenie w pierwszej fazie badań walidacyjnych.

Tabela 2. Charakterystyka rozkładu wykształcenia

\begin{tabular}{lccccc}
\multirow{2}{*}{ Grupa } & & Wyższe & Średnie & $\begin{array}{r}\text { Zawodowe } \\
\text { zasadnicze }\end{array}$ & Podstawowe \\
\cline { 2 - 6 } Kobiety & $\mathrm{n}$ & 177 & 80 & 5 & 8 \\
\cline { 2 - 6 } & $\%$ & 65,56 & 29,63 & 1,85 & 2,96 \\
\hline \multirow{2}{*}{ Mężczyźni } & $\mathrm{n}$ & 87 & 34 & 2 & 7 \\
\cline { 2 - 6 } & $\%$ & 66,92 & 26,15 & 1,54 & 5,38 \\
\hline \multirow{2}{*}{ Ogółem } & $\mathrm{n}$ & 264 & 114 & 7 & 15 \\
\cline { 2 - 6 } & $\%$ & 66,00 & 28,50 & 1,75 & 3,75 \\
\hline
\end{tabular}

Źródło: opracowanie własne

Po prezentacji charakterystyki kontrolowanych cech nie należy oczekiwać, że zostanie ona wykorzystana w interpretacji bieżących wyników pomiaru Skalą Wizerunku Miejscowości. Po pierwsze, służą one wyłącznie zdaniu sprawy ze specyfiki próby i wykorzystywaniu jej w kolejnych fazach badania do celów porównawczych i weryfikacyjnych. Po drugie, byłoby merytorycznie nieuzasadnione i błędne interpretowanie wyników pomiaru cechy narzędziem, które dopiero podlega testowaniu. Przedmiotem prezentowanego badania są własności instrumentu pomiaru cechy, a nie jej charakterystyka w określonej populacji lub próbie.

\section{Narzędzie gromadzenia danych}

Pozycje Skali Wizerunku Miejscowości wygenerowane zostały w oparciu o analizę literatury oraz wyniki badań ankietowych poświęconych jakości życia miejskiego (Pasikowski, Ratkowska-Pasikowska 2017). Ze zbioru zgromadzonych danych wydzielono próbę liczącą 49 obserwacji, która potraktowana została jako próba pilotażowa. Respondenci udzielali odpowiedzi na 70 pytań ankiety, posługując się 5-punktową szacunkową skalą aprobaty oraz udzielając odpowiedzi na otwarte pozycje kafeterii, jak również osobnych komentarzy w odniesieniu do tematu ankiety jej kwestionariusza i warunków badania. Na podstawie tych odpowiedzi utworzona została lista 15 zagadnień, które stanowiły bazę w konstrukcji puli pozycji testu. Na skalę złożyło się 15 pozycji. Do udzielania odpo- 
wiedzi przewidziana została 5-punktowa skala szacunkowa, której pozycje opisane zostały następująco: „zdecydowanie nie”, „nie” , „trochę nie i trochę tak”, „tak”, „zdecydowanie tak”. W celu poprawy jakości odpowiedzi zastosowano odwołanie do społecznego kontekstu udzielania odpowiedzi. Polegało to na poprzedzeniu pozycji skali zdaniem: „Jeśli polecałaby Pani/polecałby Pan komuś zamieszkanie w mieście (tu nazwa), to z powodu: ...".

Deklarowanie własnych ocen w sytuacji, gdy stają się one podstawą udzielanej rekomendacji aktywizuje schematy zachowań uruchamiane w sytuacjach ekspozycji społecznej. To z kolei nasila regulacyjną rolę standardów społecznych zwiększając $\mathrm{w}$ ten sposób szanse zaangażowania poczucia interpersonalnej i społecznej odpowiedzialności za dokonywane oceny, a w konsekwencji podejmowaniu próby obiektywizacji formułowanych ocen. To rozwiązanie staje się użyteczne szczególnie wówczas, gdy brak możliwości zastosowania wewnątrztestowych instrumentów kontroli wiarygodności udzielanych odpowiedzi.

Przed wykorzystaniem Skali do gromadzenia danych, jej pozycje poddane zostały profesjonalnej ocenie językowej pod względem poprawności gramatycznej i treściowej. Ostateczna wersja Skali Wizerunku Miejscowości wykorzystana w badaniu walidacyjnym zaprezentowana została w tabeli 3 .

Tabela 3. Skala Wizerunku Miejscowości

\begin{aligned} & \multicolumn{1}{c}{$\begin{array}{c}\mathrm{Nr} \\ \text { pozycji }\end{array}$} \multicolumn{1}{c}{$\begin{array}{c}\text { Jeśli polecałaby Pani/polecałby Pan komuś zamieszkanie w ... } \\ \text { (nazwa miejscowości)..., to z powodu: ... }\end{array}$} \\ & \hline 1. możliwości uzyskania pracy \\ & \hline 2. warunków przyrodniczych i krajobrazowych miasta (miejscowości) i okolic \\ & \hline 3. wyglądu centralnej części miasta (miejscowości) \\ & \hline 4. wyglądu obrzeży miasta (miejscowości) \\ & \hline 5. $\begin{array}{l}\text { troski władz i instytucji miejscowości o mieszkańców, wyrażającej się w przychyl- } \\ \text { ności mieszkańcom i gotowości udzielania im wsparcia }\end{array} \\ &$\hline 6. atrakcji kulturalnych \\ & \hline 7. atrakcji turystycznych i sportowych \\ & \hline 8. inwestycji w region \\ & \hline 9. przyjazności mieszkańców \\ & \hline 10. warunków opieki medycznej \\ & \hline 11. warunków edukacji i rozwoju kwalifikacji \\ & \hline 12. możliwości zdobycia mieszkania \\ & \hline 13. regionalnych tradycji \\ & \hline 14. kosztów życia (np. opłaty za żywność, mieszkanie, transport miejski, usługi handlowe itd.) \\ & \hline 15. możliwości dojazdów do innych miejscowości, w tym do większych miast \\ & \hline\end{aligned}

Źródło: opracowanie własne 
Dane zbierano za pomocą elektronicznego formularza. Pominięcie przez osobę wypełniającą którejkolwiek z odpowiedzi sygnalizowane było odpowiednim komunikatem. Brak udzielenia odpowiedzi na dowolną pozycję kwestionariusza uniemożliwiał przesłanie formularza.

Zestawienie formalnych własności skali znajduje się w tabeli 4 . Wybiegając do przodu, uwzględnia ono również charakterystykę podskal wyodrębnionych w toku analizy danych.

Tabela 4. Formalne własności Skali Wizerunku Miejscowości

\begin{tabular}{|lcccc}
\hline Podskala & Liczba pozycji & $\begin{array}{c}\text { Długość skali } \\
\text { szacunkowej }\end{array}$ & Wynik min & Wynik max \\
\hline 1 & 6 & $0-4$ & 0 & 24 \\
\hline 2 & 4 & $0-4$ & 0 & 16 \\
\hline 3 & 5 & $0-4$ & 0 & 20 \\
\hline Lącznie & 15 & $0-4$ & 0 & 60 \\
\hline
\end{tabular}

Źródło: opracowanie własne

\section{Procedura}

Pod koniec 2017 roku na stronie slupsk.pl oraz facebooku miasta Słupska zamieszczony został post $\mathrm{z}$ zaproszeniem do udziału w badaniach. W poście znajdował się link do strony z elektronicznym kwestionariuszem ankiety. Ankieta udostępniona była bez przerw przez okres 21 dni. Wyjaśnienia wymaga w tym miejscu decyzja co do terenu badań oraz doboru próby. W początkowym etapie badań podstawowe znaczenie miało zagwarantowanie względnie stabilnych warunków, by zmaksymalizować szanse oceny słuszności kierunku postępowań badawczych, jaki wyznacza przyjęta koncepcja zjawiska. $Z$ tego powodu zdecydowano, aby w pierwszej fazie badań nad Skalą Wizerunku Miejscowości testować je na reprezentantach średniej wielkości miasta z rozwiniętą sferą podmiejską i znajdującą się w okolicy wyraźną strukturą wiejską. Dodatkowych argumentów dostarczyła w tym zakresie idea rozmytości granicy miejscowości i przemiany przestrzeni miejskiej (Majer 2010). Taki obiekt, w założeniu, jest dla przeciętnego mieszkańca poznawczo umiarkowanie złożony, co zapewnia względnie dobre rozeznanie w charakterystyce miejscowości oraz podobny międzypodmiotowy zakres informacji na jej temat. Kluczowe znaczenie dla powodzenia wstępnej fazy badań ma także motywacja uczestników badania. Dlatego udział w badaniu był dobrowolny i poprzedzony zaproszeniem do wypełnienia elektronicznego formularza testu. W tym sensie próbę można uznać za wystarczająco dobrze reprezentującą populację mieszkańców identyfikujących się z miejscowością Słupsk, dysponującą dość dobrze ukonstytuowanym wyobrażeniem o własnościach tej miejscowości i zarazem odpowiednio zmotywowanych do dzielenia się subiektywnymi spo- 
strzeżeniami na jej temat. To założenie jest formułowane na potrzebę raportowania wyników z bieżącej fazy badań i ma charakter tymczasowy.

Badanie walidacyjne poprowadzono w trybie walidacji krzyżowej (por. Hornowska 2009), która polega na podziale zbioru danych na dwie części, z których jedna wykorzystana zostaje do analizy pozycji testu, a druga do ustalania jego struktury czynnikowej. Wydzielone części były równoliczne, a przyporządkowanie do nich obserwacji przebiegało w oparciu o losowanie. Na potrzeby badania nazwano je odpowiednio: Zbiór A i Zbiór B. W analizie danych zastosowano procedurę oceny spójności testu oraz eksploracyjną analizę czynnikową. Tę ostatnią przeprowadzono trzykrotnie, za każdym razem wykorzystując inną metodę rotacji czynników ${ }^{1}$. Najpierw dla czynników ortogonalnych, czyli nieskorelowanych. Następnie dla czynników skośnych, pomiędzy którymi dopuszcza się występowanie korelacji. Podyktowane było to brakiem założeń, co do możliwej struktury mierzonej cechy. Wnioskowanie statystyczne prowadzono na poziomie istotności $\alpha=0,05$.

W schemacie badań walidacyjnych ustala się trafność oraz rzetelność pomiaru uzyskiwanego przy pomocy testowanego narzędzia. Zazwyczaj w schemacie tym mierzona cecha traktowana jest jako ciągła i latentna (Hornowska 2009; Mańkowska 2010). Ocenie poddawany jest cały test oraz własności poszczególnych pozycji, które go tworzą. Do najpopularniejszych metod analizy danych wykorzystywanych w tym schemacie badawczym, stawiających sobie za cel jednoczenie, redukcję i klasyfikację zmiennych (odtwarzanie struktury cechy), należy analiza czynnikowa, modelowanie równań strukturalnych oraz, choć rzadziej, analiza skupień. Ta pierwsza nadal stosowana jest z przewagą nad pozostałymi i w związku $\mathrm{z}$ tym ją wybrano do analizy danych w prezentowanym badaniu. Występuje ona w dwóch odmianach: eksploracyjnej oraz konfirmacyjnej. Wybór uzależniony jest od tego, czy wstępna pula pozycji generowana jest według klucza określającego hipotetyczną strukturę zjawiska, czy też nie. Z kolei ocena spójności wewnętrznej testu uchodzi za jedną z podstawowych metod ustalania rzetelności, obok metody test-retest polegającej na co najmniej dwukrotnym pomiarze oddzielonym, jeden od drugiego, interwałem czasowym (por. Jankowski, Zajenkowski 2009). W istocie realizuje jednak także cele związane z ustalaniem trafności teoretycznej i trafności czynnikowej (Pasikowski 2017).

Przystępując do projektowania badania uwzględniona została kontrola takich zmiennych, jak płeć, wiek metrykalny, wykształcenie oraz czas zamieszkiwania. Jest to grupa cech uznawanych powszechnie za ważne w wyznaczaniu właściwo-

${ }^{1}$ Czynnikiem nazywana jest latentna zmienna, o ogólniejszym charakterze niż zmienne składające się na nią - w tym przypadku tymi składowymi zmiennymi są pozycje testu. Celem analizy czynnikowej wykorzystywanej w badaniach walidacycjnych narzędzi jest określenie latentnej struktury zjawiska wyrażającego się w odpowiedziach na pozycje testu. 
ści, na przykład wizerunku miasta (Florek, Glińska, Kowalewska 2009; Dudek-Mańkowska 2011).

Wykształcenie sprzężone jest z indywidualnymi potrzebami i oczekiwaniami, przez co indywidualny wizerunek miejscowości może się zmieniać na drodze dostrzegania możliwości realizacji tych potrzeb i oczekiwań. Na podobnej zasadzie wizerunek miejscowości determinowany może być przez płeć. Z kolei okres zamieszkiwania w danej miejscowości oraz wiek metrykalny mogą wyznaczać różnice w jej wizerunku na co najmniej dwa sposoby. Po pierwsze, wraz z upływem czasu zamieszkania poszerzać i pogłębiać może się wiedza o warunkach życia w wybranej miejscowości. Po drugie, z czasem zamieszkiwania związana może być, w określony sposób, identyfikacja z miejscowością, jej obszarem, instytucjami, grupami społecznymi i osobami w niej zamieszkującymi. To natomiast warunki, które mają zdolność różnicowania ocen.

\section{Wyniki}

Na wstępie analizie poddane zostały własności psychometryczne poszczególnych pozycji testu. Następnie na osobnym zbiorze danych przeprowadzono eksploracyjną analizę czynnikową celem odkrycia nadrzędnych zmiennych, w skład których mogłyby wchodzić indywidualne pozycje testu. To podejście pozwala zredukować liczbę zmiennych, w tym przypadku pozycji testu, do ogólniejszych wymiarów. Dzięki temu uwidoczniona zostaje struktura testu. W osobnym kroku oceniono spójność testu oraz jego podskal wyodrębnionych w toku analizy czynnikowej.

\section{Analiza mocy dyskryminacyjnej oraz zgodności wewnętrznej testu}

Ocena własności testu rozpoczęta została od przybliżenia charakterystyk poszczególnych pozycji. Zasadnicza uwaga skupiona została na korelacji pozycji z testem, wyrażanej jako moc dyskryminacyjna, oraz ich ,podatności” na wybór skrajnych odpowiedzi. Ta pierwsza określana jest jako moc dyskryminacyjna i pozwala ocenić zbieżność odpowiedzi na daną pozycję testu z odpowiedziami na pozostałe pozycje. Ta druga pozwala kontrolować zgeneralizowaną w grupie skłonność do wyboru skrajnych pozycji skali szacunkowej, co traktowane jest jako czynnik zniekształcający wyniki analiz.

Wartość współczynników mocy dyskryminacyjnej okazała się stosunkowo wysoka (tab. 5). W pierwszej grupie jedynie w jednym przypadku charakteryzowała się wartością niższą niż 0,5 (choć to nadal satysfakcjonująca wartość) przy korelacyjnym współczynniku zgodności wewnętrznej $\alpha$ Cronbacha $=0,902 \mathrm{Na}$ uwagę zasługuje także, że wszystkie pozycje okazują się mieć udział w łącznej korelacji zachodzącej między pozycjami testu. Wskazuje na to wartość $\alpha$ Cronbacha malejąca przy usuwaniu każdej pozycji z osobna. W zbiorze danych nie wystąpił 
też efekt potakiwania ani zaprzeczania. Taki wniosek można wyciągnąć przyglądając się współczynnikom aprobaty. Współczynnik aprobaty przyjmuje wartości z przedziału 0-1. Im bliższe są one zeru lub jedności, tym bardziej wskazują na zgeneralizowane w próbie wybieranie skrajnych wartości skali szacunkowej.

Tabela 5. Własności pozycji testu (Zbiór A)

\begin{tabular}{rccc}
\hline $\begin{array}{c}\text { Pozycja } \\
\mathrm{nr}\end{array}$ & $\begin{array}{c}\text { Współczynnik } \\
\text { aprobaty }\end{array}$ & $\begin{array}{c}\text { Moc } \\
\text { dyskryminacyjna }\end{array}$ & $\begin{array}{c}\alpha \text { Cronbacha } \\
\text { po usunięciu }\end{array}$ \\
\hline 1. & 0,33 & 0,43 & 0,90 \\
\hline 2. & 0,68 & 0,56 & 0,90 \\
\hline 3. & 0,56 & 0,65 & 0,89 \\
\hline 4. & 0,51 & 0,51 & 0,90 \\
\hline 5. & 0,41 & 0,65 & 0,89 \\
\hline 6. & 0,42 & 0,68 & 0,89 \\
\hline 7. & 0,43 & 0,68 & 0,89 \\
\hline 8. & 0,38 & 0,69 & 0,89 \\
\hline 9. & 0,56 & 0,52 & 0,90 \\
\hline 10. & 0,32 & 0,61 & 0,90 \\
\hline 11. & 0,41 & 0,70 & 0,89 \\
\hline 12. & 0,38 & 0,53 & 0,90 \\
\hline 13. & 0,49 & 0,57 & 0,90 \\
\hline 14. & 0,52 & 0,57 & 0,90 \\
\hline 15. & 0,41 & 0,50 & 0,90 \\
\hline
\end{tabular}

Źródło: opracowanie własne

\section{Struktura testu i zgodność wewnętrzna wyodrębnionych skal}

Podkreślenia wymaga, że liczba obserwacji uwzględnionych w analizie struktury testu jest 13-krotnie większa niż liczba pozycji testu. Podobna przewaga stanowi podstawowy warunek prowadzenia wiarygodnej analizy czynnikowej. W przypadku początkowej puli pozycji testowych zastosowanie analizy czynnikowej w celu zredukowania liczby zmiennych okazało się zasadne, na co wskazał satysfakcjonujący współczynnik korelacji Kaisera-Mayera-Olkina $(\mathrm{KMO}=0,86)$ oraz istotny statystycznie wynik testu sferyczności Bartletta $\left(c h i^{2}=1339,09, \mathrm{df}=105\right.$, $\mathrm{p}=0,000)$ świadczący o tym, że korelacje w macierzy wyników były wyraźnie wyższe niż zero. Test osypiska Cattela wskazał na obecność 2 czynników, jednak zgodnie z kryterium Kaisera wysokość wartości własnych powyżej 1 pozwoliła 
zasadnie uwzględnić trójczynnikową strukturę testu. Wartość własna czynnika pierwszego, drugiego i trzeciego wyniosła odpowiednio: 6,18, 1,46 i 1,15. Współczynnik MSA (measure of sampling adquacy) będący miarą adekwatności doboru indywidualnych zmiennych (tu pozycje testu) dla każdej z pozycji testu osiągał wartość powyżej 0,5 . Przeciętna ich wysokość wynosiła 0,85 , co świadczy o odpowiedniej wysokiej korelacji cząstkowej dla każdej z pozycji. Oznacza to, że nie było potrzeby usuwania żadnej z nich przed przystąpieniem do procedury analizy czynnikowej. Zastosowano 3 metody rotacji czynników, ortogonalną Varimax oraz dwie dla czynników skośnych, tj. Oblimin i Promax. Podyktowane zostało to wysokością współczynników korelacji pomiędzy czynnikami wyodrębnionymi przy pomocy rotacji ortogonalnej Varimax (tab. 6). Wszystkie współczynniki okazały się statystycznie istotne.

Tabela 6. Interkorelacje czynników wyodrębnionych metodą Oblimin i Promax

\begin{tabular}{|c|c|c|c|c|c|c|}
\hline \multirow{2}{*}{$\begin{array}{c}\text { Czynnik } \\
\mathrm{nr}\end{array}$} & \multicolumn{3}{|c|}{ Oblimin } & \multicolumn{3}{c|}{ Promax } \\
\cline { 2 - 7 } & 1 & 2 & 3 & 1 & 2 & 3 \\
\hline 1. & 1 & & & 1 & & \\
\hline 2. & $-0,421$ & 1 & & $-0,657$ & 1 & \\
\hline 3. & $-0,602$ & 0,349 & 1 & $-0,737$ & 0,642 & 1 \\
\hline
\end{tabular}

Źródło: opracowanie własne

Przegląd ładunków czynnikowych dla poszczególnych pozycji testu zwróconych odmiennymi metodami rotacji (tab. 7) pozwala dostrzec zdecydowane podobieństwo rezultatów. Zwiększa ono wiarygodność zgrupowania pozycji testu w ramach wyodrębnionych czynników oraz trójczynnikową strukturę jako najlepiej opisującą zebrane wyniki. Zakres wariancji wyników pomiaru wyjaśnianej przez test i poszczególne jego czynniki jest satysfakcjonujący, jak na narzędzia pomiaru psychologicznego. Widoczne różnice pomiędzy metodami rotacji są wynikiem własności tych metod. Z kolei podobieństwo pomiędzy metodą Varimax oraz Promax w zakresie wysokości wyjaśnianej wariancji jest wynikiem dążenia w tej ostatniej do takiego obrotu osi (czynników) względem chmury punktów wyrażających wyniki pomiaru, aby zminimalizować ich skośność. Innymi słowy, celem rotacji Promax jest ustawienie osi względem siebie w możliwie najbardziej prostopadłym ułożeniu. Na pierwszy czynnik złożyło się 6 pozycji (nr 1, 10, 11, $12,14,15)$. Na czynnik drugi przypadły 4 pozycje (nr 5, 6, 7, 8). Z kolei czynnik trzeci reprezentowany jest przez 5 pozycji testu (nr 2, 3, 4, 9, 13). Wyodrębnionym czynnikom nadano następujące nazwy: czynnik pierwszy - „Podstawowe warunki życia”, czynnik drugi - „Troska o mieszkańców”, czynnik trzeci - „Estetyka miejsca". 
Tabela 7. Wyniki eksploracyjnej analizy czynnikowej metodą rotacji Vrimax, Oblimin i Promax

\begin{tabular}{|c|c|c|c|c|c|c|c|c|c|}
\hline \multirow{3}{*}{$\begin{array}{c}\text { Pozycja } \\
\text { nr }\end{array}$} & \multicolumn{3}{|c|}{ Varimax } & \multicolumn{3}{|c|}{ Oblimin } & \multicolumn{3}{|c|}{ Promax } \\
\hline & \multicolumn{3}{|c|}{ Czynnik } & \multicolumn{3}{|c|}{ Czynnik } & \multicolumn{3}{|c|}{ Czynnik } \\
\hline & 1 & 2 & 3 & 1 & 2 & 3 & 1 & 2 & 3 \\
\hline 1. & 0,698 & 0,148 & 0,184 & 0,781 & & & 0,905 & $-0,194$ & \\
\hline 2. & & & 0,876 & & & 0,908 & $-0,243$ & $-0,163$ & 1,100 \\
\hline 3. & 0,211 & 0,345 & 0,560 & 0,107 & 0,272 & 0,465 & & 0,219 & 0,522 \\
\hline 4. & 0,324 & 0,253 & 0,484 & 0,281 & 0,129 & 0,384 & 0,235 & & 0,416 \\
\hline 5. & 0,385 & 0,462 & 0,269 & 0,284 & 0,400 & & 0,281 & 0,395 & \\
\hline 6. & 0,239 & 0,841 & 0,186 & & 0,938 & & & 1,051 & $-0,159$ \\
\hline 7. & 0,246 & 0,781 & 0,360 & & 0,834 & 0,132 & & 0,904 & \\
\hline 8. & 0,474 & 0,555 & 0,176 & 0,361 & 0,499 & & 0,392 & 0,516 & $-0,149$ \\
\hline 9. & 0,237 & 0,174 & 0,446 & 0,207 & & 0,382 & 0,155 & & 0,428 \\
\hline 10. & 0,573 & 0,235 & 0,167 & 0,599 & & & 0,687 & & \\
\hline 11. & 0,638 & 0,314 & 0,174 & 0,648 & 0,141 & & 0,744 & & $-0,120$ \\
\hline 12. & 0,525 & 0,177 & 0,132 & 0,564 & & & 0,653 & & \\
\hline 13. & 0,337 & 0,392 & 0,458 & 0,246 & 0,301 & 0,318 & 0,197 & 0,256 & 0,327 \\
\hline 14. & 0,329 & 0,130 & 0,341 & 0,337 & & 0,262 & 0,335 & & 0,275 \\
\hline 15. & 0,575 & 0,140 & 0,137 & 0,638 & & & 0,742 & $-0,130$ & \\
\hline$\% \mathrm{~S}^{2}$ & 18,3 & 16,4 & 14,9 & 17,6 & 14,7 & 10,2 & 22,4 & 17,0 & 14,1 \\
\hline $\begin{array}{c}\% \mathrm{~S}^{2} \\
\text { tącznie }\end{array}$ & & 49,6 & & & 42,5 & & & 53,5 & \\
\hline
\end{tabular}

Źródło: opracowanie własne

Zgodność wewnętrzna poszczególnych skal oceniona została z pomocą dwóch współczynników korelacyjnych: $\alpha$ Cronbacha oraz Spearmana-Browna (tzw. współczynnik rzetelności połówkowej). Wysokość współczynnika $\alpha$ Cronbacha dla podskali pierwszej, drugiej i trzeciej wyniosła odpowiednio: $0,77,0,86$ oraz 0,78 . Z kolei współczynnik Spearmana-Browna dla poszczególnych podskal przyjął wartości: $0,74,0,89,0,79$. Korelacja pomiędzy wszystkimi pozycjami skali wyniosła 0,895 $\alpha$ Cronbacha oraz $0,92 \mathrm{w}$ obliczeniu z zastosowaniem formuły Spearmana-Browna. Analiza mocy dyskryminacyjnej pozycji testu dostarczyła wyników wskazujących na satysfakcjonujące związki poszczególnych pozycji ze skalami, w skład których wchodzą oraz z całym testem. Ponowny przegląd własności pozycji testu dostarcza informacji świadczących o wyraźnej i zadowalającej spójności testu (tab. 8). 
Tabela 8. Własności pozycji testu (Zbiór B)

\begin{tabular}{|c|c|c|c|c|c|c|}
\hline $\begin{array}{l}\text { Czynnik/ } \\
\text { Podskala }\end{array}$ & $\begin{array}{c}\text { Pozycja } \\
n r\end{array}$ & $\begin{array}{l}\text { Współ- } \\
\text { czynnik } \\
\text { aprobaty }\end{array}$ & $\begin{array}{c}\text { Moc } \\
\text { dyskrymi- } \\
\text { nacyjna }\end{array}$ & $\begin{array}{c}\alpha \text { Cron- } \\
\text { bacha po } \\
\text { usunięciu }\end{array}$ & $\begin{array}{c}\text { Moc } \\
\text { dyskrymi- } \\
\text { nacyjna } \\
\text { (cały test) }\end{array}$ & $\begin{array}{l}\alpha \text { Cron- } \\
\text { bacha po } \\
\text { usunięciu }\end{array}$ \\
\hline \multirow{6}{*}{$\begin{array}{c}\text { (1) } \\
\text { Podstawo- } \\
\text { we warun- } \\
\text { ki życia }\end{array}$} & 1 & 0,27 & 0,61 & 0,74 & 0,57 & 0,889 \\
\hline & 10 & 0,30 & 0,57 & 0,75 & 0,55 & 0,893 \\
\hline & 11 & 0,38 & 0,62 & 0,74 & 0,63 & 0,888 \\
\hline & 12 & 0,35 & 0,52 & 0,76 & 0,47 & 0,888 \\
\hline & 14 & 0,57 & 0,43 & 0,78 & 0,45 & 0,886 \\
\hline & 15 & 0,36 & 0,50 & 0,77 & 0,47 & 0,885 \\
\hline \multirow{4}{*}{$\begin{array}{c}(2) \\
\text { Troska } \\
\text { o miesz- } \\
\text { kańców }\end{array}$} & 5 & 0,35 & 0,60 & 0,86 & 0,63 & 0,882 \\
\hline & 6 & 0,41 & 0,77 & 0,79 & 0,65 & 0,885 \\
\hline & 7 & 0,43 & 0,77 & 0,79 & 0,73 & 0,893 \\
\hline & 8 & 0,33 & 0,67 & 0,83 & 0,67 & 0,890 \\
\hline \multirow{5}{*}{$\begin{array}{l}\text { (3) } \\
\text { Estetyka } \\
\text { miejsca }\end{array}$} & 2 & 0,72 & 0,61 & 0,73 & 0,45 & 0,886 \\
\hline & 3 & 0,51 & 0,61 & 0,72 & 0,58 & 0,892 \\
\hline & 4 & 0,48 & 0,54 & 0,75 & 0,58 & 0,885 \\
\hline & 9 & 0,56 & 0,47 & 0,77 & 0,46 & 0,893 \\
\hline & 13 & 0,46 & 0,56 & 0,74 & 0,65 & 0,893 \\
\hline
\end{tabular}

Źródło: opracowanie własne

\section{Wnioski i dyskusja}

W wyniku przeprowadzonych badań udało się ustalić trójczynnikową strukturę Skali Wizerunku Miejscowości. Część pozycji gromadzi dane o podstawowych warunkach życia w miejscowości, część o działaniach władnych podmiotów na rzecz podtrzymywania życia społecznego w miejscowości i gotowości udzielania wsparcia mieszkańcom, część wreszcie dostarcza informacji na temat estetyki miejscowości, to znaczy jej wyglądu i znamiennych dla niej akcentów kulturowych oraz cech przyrodniczo-krajobrazowych otoczenia, w jakim się ta miejscowość znajduje. Tak scharakteryzowana struktura znajduje uzasadnienie w istniejących w literaturze wskazówkach na temat warunków kształtowania się poznawczej perspektywy miejscowości (Pióro 1962; Majer 2010). Poszczególne pozycje skali charakteryzują się zadowalającymi własnościami psychometrycznymi w zakresie trafności czynnikowej oraz zgodności wewnętrznej podskal, które wy- 
odrębnione zostały w toku analizy. Zaletą skali może być jej długość pozwalająca dokonywać pomiaru nawet w mniej sprzyjających warunkach obarczonych ryzykiem rozpraszania uwagi respondentów. Jednocześnie wadę stanowić może względna ogólność niektórych z jej pozycji. Do słabych stron zaprezentowanych wyników badań należy to, że pochodzą one z pierwszej fazy projektu walidacji Skali Wizerunku Miejscowości. Z tego powodu należy traktować je z ostrożnością.

Dalsze prace nad skalą polegać będą na weryfikacji dotychczas uzyskanych rezultatów oraz na ocenie trafności kryterialnej i ocenie stabilności bezwzględnej wyników pomiaru. Ocena trafności kryterialnej polega na badaniu związków wyników pomiaru testem z wynikami pomiaru innymi narzędziami mierzącymi podobne zmienne (stąd nieoceniona rola poszukiwania podobnych konstruktów, jak przywoływane wyżej postawy lub przywiązanie do miejsca, miejscowości i miasta) oraz pozatestowymi kryteriami, jakimi mogą być faktyczne zachowania lub ich rezultaty. Z kolei w ocenie stabilności bezwzględnej chodzi o ocenę zbieżności wyników pomiaru w czasie. W tym celu uwzględnia się kilkutygodniowy odstęp zanim nastąpi powtórzenie badania. Ocena stabilności bezwzględnej, tzw. test-retest, realizowana jest zatem z użyciem tego samego narzędzia i w odniesieniu do tej samej próby. Aby jednak możliwe było uznanie nowo powstałego narzędzia za gotowe do powszechnego użytkowania w diagnozie wizerunku miejscowości, niezbędny jest okres prowadzenia badań z jego użyciem mających na celu monitorowanie zachowania się skali w nowych warunkach i w odniesieniu do przeróżnych miejscowości. Już teraz jednak parametry tej skali przedstawiają się obiecująco.

$\mathrm{Na}$ koniec warte uwagi jest spostrzeżenie, że po ustaleniu stabilności parametrów Skali Wizerunku Miejscowości nadawać się ona będzie nie tylko do pomiaru indywidualnego, ale i grupowego. Choć w tym celu niezbędne jest dysponowanie uzasadnionym kryterium podziału zbiorowości mieszkańców, by następnie w drodze zastosowania metod porównań międzygrupowych wykazywać różnice i podobieństwa pomiędzy danymi grupami społecznymi lub reprezentantami określonych kategorii społecznych w zakresie tejże cechy. To dość powszechny sposób wykorzystywania instrumentów pomiaru indywidualnego i wart podkreślenia w kontekście problematyki wdrażania innowacji społecznych, którego efektywność uzależniona jest od rozpoznania istniejących warunków psychologicznych i społecznych.

\section{Literatura}

Dej M., Zajda K., 2016, Kontrurbanizacja i jakość życia na wsi, „Acta Universitatis Lodziensis. Folia Sociologica", 57: 51-66.

Dolnicar S., Grun B., 2013, Validly measuring destination image in survey studies, „Journal of Travel Research”, 52(1): 3-14. 
Dudek-Mańkowska S., 2011, Koncepcja wizerunku miasta, [w:] Grzegorczyk A., Kochaniec A. (red.), Kreowanie wizerunku miast, Wydawnictwo Wyższej Szkoły Promocji, Warszawa: 42-67.

Echtner C.M., Ritchie J.R., 2003, The Meaning and Mesurement of Destination Image, „The Journal of Tourism Studies”, 14(1): 37-48.

Florek M., Glińska E., Kowalewska A., 2009, Wizerunek miasta: Od koncepcji do wdrożenia, Wolters Kluwer, Warszawa.

Gallarza M., Saura I.G., Garcia H.C., 2002, Destination Image: Towards a Conceptual Framework, „Annals of Tourism Research”, 29(1): 56-78.

Hornowska E., 2009, Testy psychologiczne. Teoria i praktyka (wyd. 4), Wydawnictwo Scholar, Warszawa.

Jankowski K., Zajenkowski M., 2009, Metody szacowania rzetelności pomiaru testem, [w:] Fronczyk K. (red.), Psychometria. Podstawowe zagadnienia, Wyższa Szkoła Finansów i Zarządzania w Warszawie, Warszawa: 84-110.

Jenkins O.H., 1999, Understanding and Measuring Tourist Destination Images, „International Journal of Tourism Research", 1: 1-15.

Lewicka M., 2005, Ways to make people active: The role of place attachment, cultural capital, and neighborhood ties, ,Journal of Environmental Psychology”, 25: 381-395.

Lynch K., 1960/1990, The Image of the City, (wyd. 20), The MIT Press, Cambridge.

Majer A., 2010, Socjologia i przestrzeń miejska, Wydawnictwo Naukowe PWN, Warszawa.

Mandal A., Moroń M., 2016, Skala przywiązania do miejsca-polska adaptacja The Measure of Place Attachment D. Williamsa i J. Vaske'a (2003), „Psychologia Społeczna”, 2(37): 211-222.

Mańkowska M., 2010, Wprowadzenie do psychometrii, Wydawnictwo KUL, Lublin.

Michalska A., 2002, Psychospołeczne więzi z miejscem zamieszkania na przykładzie wybranych osiedli łódzkich $i$ wsi Brudzewice, ,Studia Regionalne i Lokalne”, 1(8): 79-100.

Michalska A., 2003, Indywidualny i kolektywny wymiar identyfikacji przestrzennej, „Studia Regionalne i Lokalne", 4(14): 77-90.

Nowacki M., Zmyślony P., 2011, The Measurement of City Image: Urban Tourism Market Segmentation, „Current Issues of Tourism Research”, 1(1): 10-18.

Pasikowski S., 2017, Metodologiczny kontekst pojęcia dyskryminacji w badaniach nad dyskryminacja społeczna, „Przegląd Badań Edukacyjnych”, 24(1): 223-237.

Pasikowski S., Ratkowska-Pasikowska J., 2017, Jakość życia Stupszczanek. Sprawozdanie z badań sondażowych, Niepublikowany raport wykonany na zlecenie Urzędu Miasta Słupska z rekomendacji Rady Kobiet przy Prezydencie Miasta.

Pióro Z., 1962, Ekologia społeczna w urbanistyce, Arkady, Warszawa.

Salesses P., Schechtner K., Hidalgo C.A., 2013, The Collaborative Image of The City: Mapping the Inequality of Urban Perception, „PLoS One”, 8(7): 1-12.

Starosta P., Brzeziński K., 2014, The Structure of Social Trust in Post-industrial Cities of Central and Eastern Europe, „Przegląd Socjologiczny”, 63(1): 49-79.

Sztabiński P.B., Sztabiński F., 1997, Przywiazanie do miejsca zamieszkania jako wymiar polskiego tradycjonalizmu, [w:] Domański H. (red.), Elementy nowego ładu, Wydawnictwo IFiS PAN, Warszawa: 256-269. 
Tobiasz-Lis P., 2016, Uwarunkowania rozwoju a wizerunek miasta. Przykład Łodzi, „Barometr Regionalny”, 14(2): 85-94.

Wojciszke B., 2011, Psychologia spoteczna, Wydawnictwo Scholar, Warszawa.

Zajda K., 2017a, Wdrażanie innowacji społecznych przez wiejskie organizacje pozarzadowe, „Wieś i Rolnictwo”, 177: 97-114.

Zajda K., 2017b, Non-governmental organizations' collaboration with local entities and their potential for implementing social innovations, „Acta Innovations”, 24: 14-21.

\title{
VALIDATION OF THE PLACE IMAGE SCALE - THE FIRST PHASE OF RESEARCH
}

\begin{abstract}
The article presents the idea of place image as a city, town or village. In the first part it focus on a review of selected methods and tools for measuring those and similar features. Next, the results of research on the original instrument for measuring the place image were presented. The investigation encompassed 400 residents. As a result of the factor analysis used, it was determined that the scale structure has a three parts. The psychometric parameters of the scale positions turned out to be satisfactory, and the coefficients of its internal consistency were acceptable.
\end{abstract}

Keywords: Place Image Scale, measurement, validation.

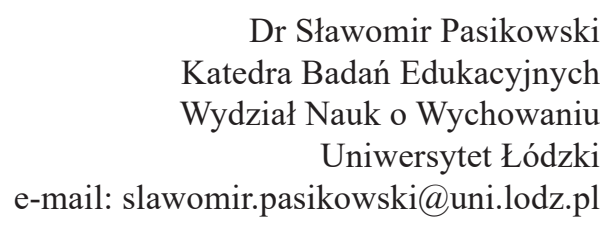

